\title{
絹練石鹼の精練力檢定方法に就て
}

禁學士 角替利策

(炤和三年畞月二十四日受理)

目次

1. 緹 言

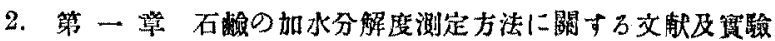

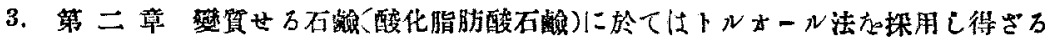
ここ前其の理由に就て

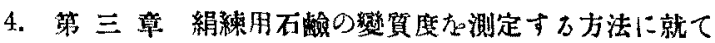

5. 概

括

6. 引用费目炊

緒喜

現今一般的に探用せられつつある絹の精練は石簽によるものなら而して或る種 の石龢の絹に對する精練力（或は除膠力）を實際に絹を精練する以前に於て盘別 するここを得ば絹業者にをり少からす便利なりご雖も現今絹練用石簽の精練力を 制別すべき方法として一般に認められたるものなし之著者が本啡究を企てたる所 以なb著者は暴きに石䌞の水溶液中に於ける加水分解に就き研然し其の大小該

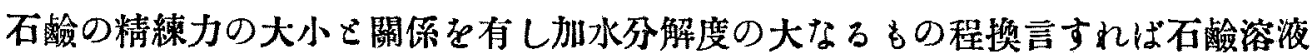
のアルカリ度の大なるすの程絴に對する精練力の大なること支確め絹㸁試驗所報 告第 2 卷中に發表せ り然るに石䩎の加水分解度测定の方法は一にして止まらす即 ち酸による滴定法トルォール法監析法並電氯傳導度测定による万法等を數人得へ く而して各方法間に山手續の繁闗、测定結果の正確度等幾多の得失あり從て各方 法間の優少に關しては種々議論の存する所なるへしと雖も余か實羷せる範圍に於

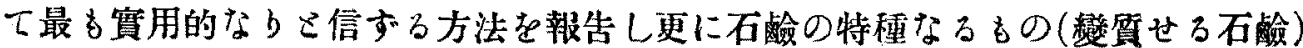
に於ては加水分解度の大小は其测定の方法如何により精練力の大小を全く相反す る場合あるここを惰驗せるが故に併せて荮に報告し更に加水分解度の測定により 絹練石獣の變質の程度（精練力減殺の程度）を制別する一方法を提唱せんこす

\section{第一章 石䩎の加水分解度測定方法に關する文献立賽驗}

從隶知られたる加水分解度測定方法は次の數種なる

I. 籃析法 II. 滴定法 III. トルォール法 IV. 電氯傳導度法 
I. 鹽析法 (Salting out-method)

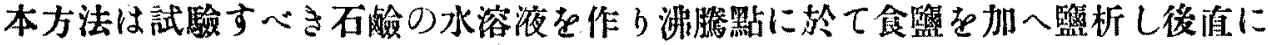
濾過し滤紙上の未分解石䀫こ脂肪酸さの混合物を食監水を以て洗滌し酒精に溶解 し遊離脂肪酸を滴定する方法なり如斯き方法により實驗せる余の試驗成綪はステ フリン酸、バルミチン酸及オレイン酸の曹達石醶に於ては後に示す他の方法に上 り測定せる加水分解度に比し著しく小なるたのにして而も該加水分解度の大小と 精練力の大小こは一致するものにあらすして如斯き方法に基く石畧の加水分解度 は精練力る表はするのにあらざるなり

II. 滴定法 (Titration-method)

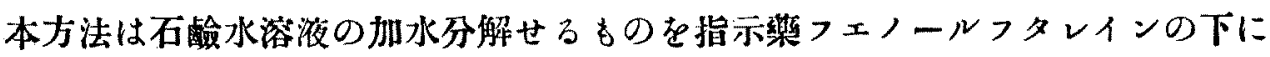

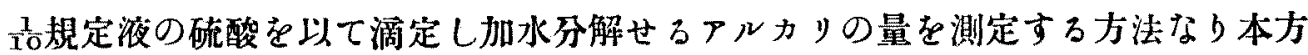

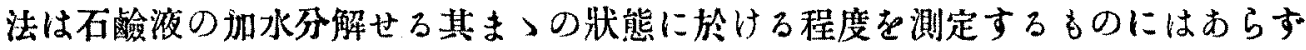
して酸の滴下によりアルカリが中和せらるつ時新に石畧の一部が分解せられ順次 如斯くして結局最後の平衡狀態る測定するものなるが故に加水分解度さ云はたよ

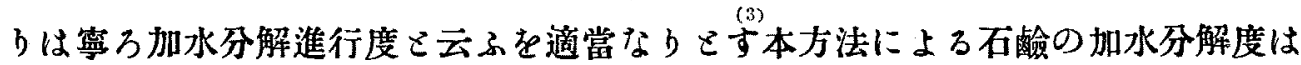
實際該石䶨による絹の精練力を現はすが故に本方法によりて測定せる結果より精 練力る檢定し得へし（英文闌 Table I, II, III，致）

\section{III. トルオール法 (Toluene-method)}

本方法の滴定法己基万所は加水分解により生成せらる〉脂肪酸を測定するすの

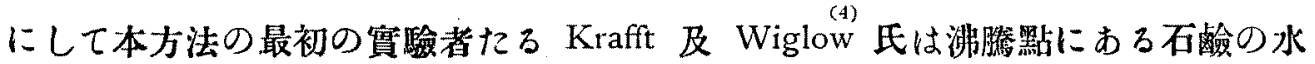

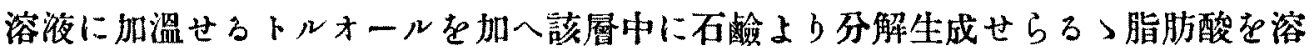
出せしめ後石檢の液さ分矍しトルオールは蒸溜し去り以て脂肪酸の量を湘定する

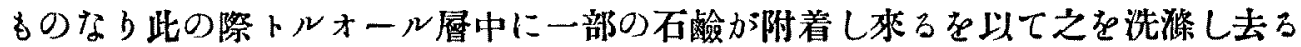

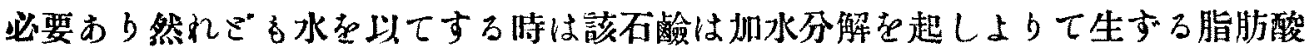
はトルオール層中に移動し結果過大となるが故に余は之る改め洗滁するここ無く

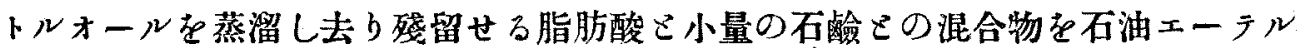
にて處理し以て脂肪酸夿分離定量する加或は酒精に溶解し漂度躰知のアルカリに て滴定するか何れかの方法を探用せり本方法による测定結果は滴定法の場合已同 樣の傾向にして從つて其の大小は精練力の大小と關係を有するが故に石鹼の精練 力检定の方法として探用し得心し（英文闌 Table IV 尔照) 
IV. 電氣傳導度法 (Electro-Conductivity method)

本方法は Mc Bain Eによりて探用せられてる方法にして先つ可检液の電氮的 抵抗老 Wheatstone Bridgeにより測定し次に傳導度を算出し之に俄り加水分解度

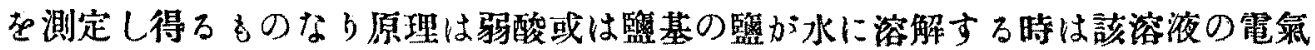

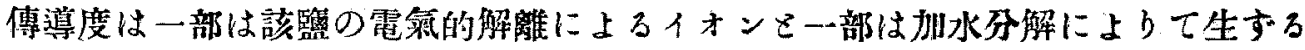

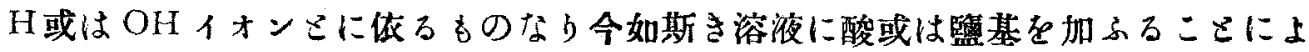

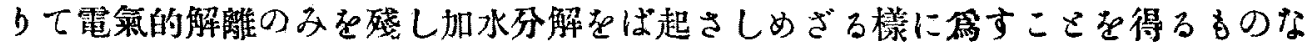

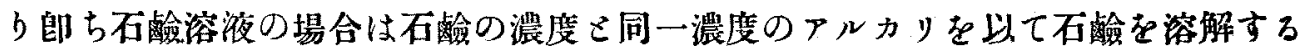
時は石踰は加水分解支起さざるが故に該石畧液の電氣傳導は單に解離により生す るイォンのみによりて篇さるっなりされば石龉の水溶液に於ける電氮傅導度、石 畧をアルカリに溶解せる場合の電氮傳導度亚該アルカリの電氮傳導度を測定する 時は公式に從ひ加水分解度を算出するここ得へし(英文㦨參照)本方法は上記の 他の方法とは異り加水分解せる其のま〉の狀態に於けるるの起测定するるのなる

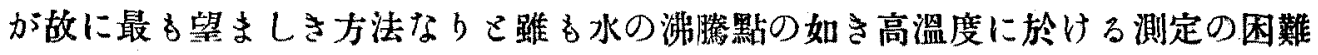
なるここ、特殊なる裝置を要するここ、傳導度用水の調製等搷雜なること多く普通 石醶を使用する工場にて探用し難し又余の實驗に於ても一定の結果を得るここ困 難なりき以上の望驗に基き絹練用石龉の精練力は其水溶液に於ける加水分解度を 滴定法又はトルオール法により測定せるものの大小民關係を有するが故に該石醶 の加水分解度測定に上り絹に對する精練力を測定し得へし

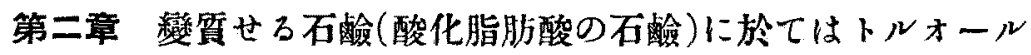
法を探用し得ざるここ並其理由に就て

トハオール法並滴定法による加水分解度を比較する時は後者が常に大なる結果 を示す事は英文闌に記載せる第四表に示す所なり然るに余か眝藏中に於て變喟せ

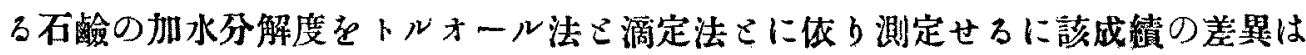

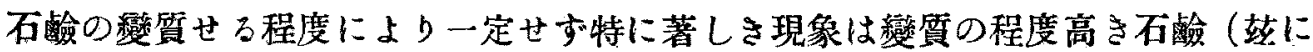

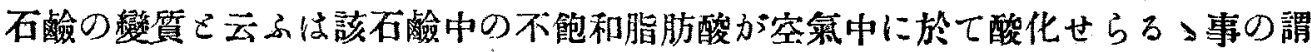
にして其程度により石猃は褐色より暗褐色を呈するに到るのみならす所謂汗なる すのを生す而して該汗の多少は變質の度の大小を示すものなるここ余等の實驗せ る所にして之が研究成績は「所謂石䶨の汗に關する研究」さ題して他日墢表する 所ある可し）に於ては逆にトルォール法による結果が潭定法による結果より大な 


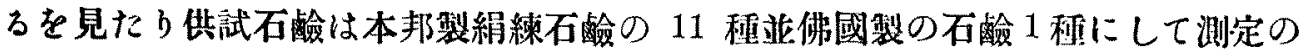
結果は下の如し

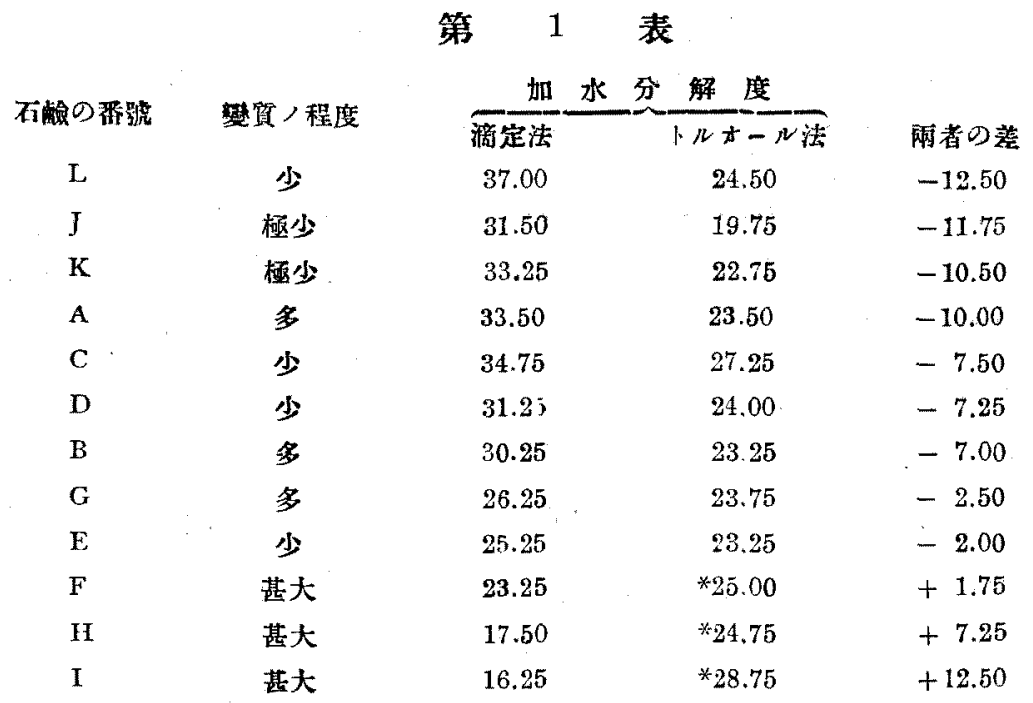

酸化するここ無き铇和脂肪酸及酸化し難きオレイン酸の石酹に於ては常にトル オール法による加水分解度が滴定法による結果より小なるここ第一章に記逝せる

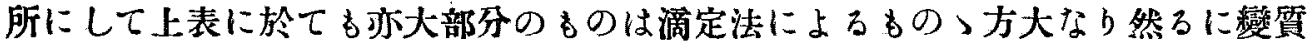
の程度最る大なる石睑郎ち F, H 及 I の 3 種に於てはトルォール法による加水 分解度が却つて滴定法に上る結果上り大なる成績を示せり之れ何の故なりや之が 原因の探求は與味ある問題なり何こなれば第2表に示す如く精練力の間にも他を 異なる關係を有するが故なり郎ちトルオール法により測定せる結果最大なる加水 分解度走示せる石鹼 $F, H$ 及 I の精練力は却つて他上万著しく小なる結果を示せ ろ事なり（精練力は生絲を精練し其練減步合にて示す）

第 2 表

石龄の番躆

I.

$\mathrm{J}$

K

A

C

D

B

滴定法

$37.00 \%$

31.50

33.25

33.50

34.75

31.25

30.25
$24.50 \%$

19.75

22.75

23.50

27.25

24.00

23.25
練減步合(綪練力)

$15.94 \%$

15.83

15.89

14.85

15.46

14.09

15.26 


\begin{tabular}{rrrr}
\hline G & 26.25 & 23.75 & 13.12 \\
E & 25.25 & 23.25 & 13.16 \\
F & 23.25 & $* 25.00$ & $* 11.61$ \\
H & 17.50 & $* 24.75$ & $* 11.89$ \\
I & 16.25 & $* 28.75$ & $* 11.71$
\end{tabular}

上表に依れば滴定法により測定せる場合最す小なる加水分解度を示せるものが トルォール法に上る時は反つて最大の加水分解度を示したり而して滴定法に上る 加水分解度の大小は能く精練力の大小を表はせぎる反之してトルォール法に依る ものは精練力の大小と相反する結果を示せるなる

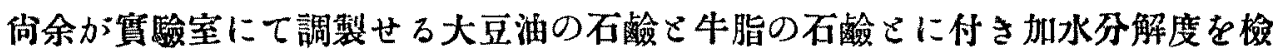
定せるに該結果は下の如し但し兩者共調彆後約五々月を經過せるるのにして大豆

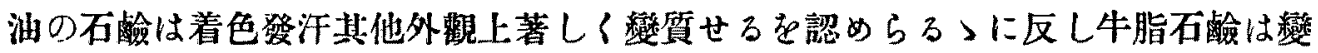
質するここ極めて少きすのなり（石睑液の濃度其他英文闌參照）

石飱の種類

大豆油石䕆

牛 脂 石 㖁
第 3 表

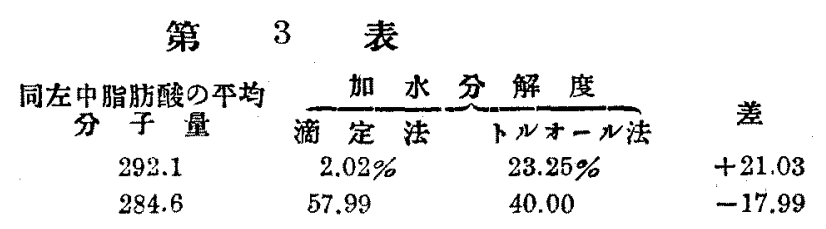

上表によれば大豆油の石畧は變質甚しき前記 F, H 及 I な3 3 個の石簽と同一 傾向を加水分解度の上に表はせるものなり如斯く加水分解度が測定の方法により

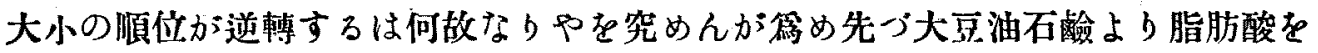
分離採收し沸騰點 $80^{\circ} \mathrm{C}$ 以下の石油エーラルを以て處理し可溶性のるの民不可溶 性のものコに分離せ 該結果は後者即ち酸化脂肪酸は實に $48.5 \%$ 多量なるに牛 脂石羷に於ては酸化脂肪酸僅かに $3 \%$ に過ざざるここを胃出したらされば該酸化

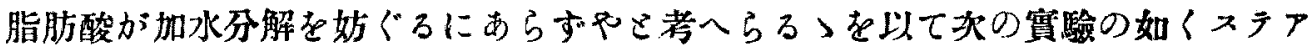
リン酸の加水分解度に及士酸化脂肪酸及非酸化脂肪酸の影響を試䛗せ b試驗の方 法はフラアリン酸石鹼 $\frac{1}{50} \mathrm{~N}$ 液中に該石鹼中に含有せらろつ脂肪酸の $20 \%$ に相 當する酸化脂肪酸及非酸化脂肪酸を添加し以て满定法により加水分解度を試驗せ り該結果は下の如し

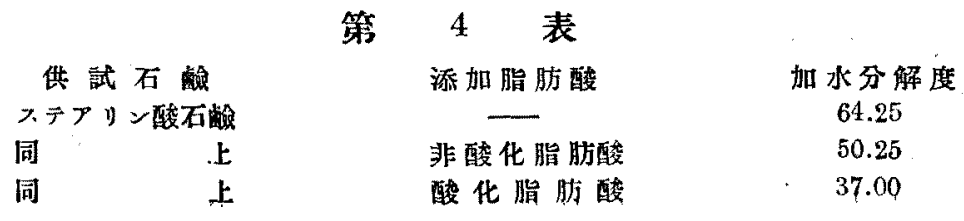


上表の結果に徽し酸化脂肪酸は非酸化脂肪酸に比し石鹼の加水分解を妨ぐる力 道かに大なるここを知れる

本結果上り考察すれば滴定法に於てはアルカリは順次に酸により中和せらるつ が故に加水分解を妨ぐる作用を篇すものは主さして脂肪酸なりされば酸化脂肪酸

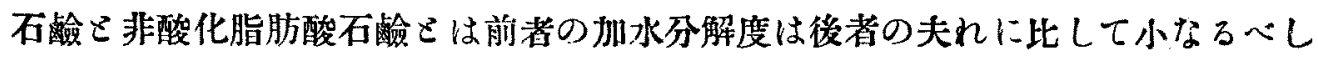
何さなれば加水分解により生成せらるつ酸化脂肪酸力; 非酸化脂肪酸より加水分解 を妨ぐる力大なればなっ第二表中酸化度の大なる石畧の滴定法に上る加水分解度 の小なるは之が篇めなり然るにトルオール法に於ては加水分解により生成せらる >脂肪酸は順次トルォール層中に溶出せらるつを以て加水分解を妨ぐる。のはア ルカリなりされば此の場合加水分解度は脂肪酸の性質によb其程度定まる隗ち該 脂肪酸が佨和なるや不饱和なりや或は高級なりや低級なりやにより定まるなり

要之するに酸化脂肪酸の石酹に於ては普通の石畧とは異りトルオール法による 加水分解度の大小は精練力の大小飞相反するものにして酸化脂肪酸の石醶或は之 を多量に合有する石簽の精練力の檢定に當りてはトルオール法を探用するここ能 はざるものなり

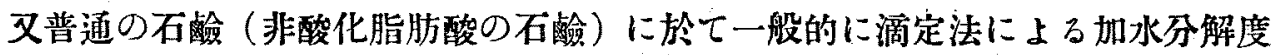
がトルオール法の場合上り大なるはアルカリが石畧の加水分解を妨ぐる力は脂肪 酸の同作用に比して大なるが故なりと云ふを得へく又更に酸化脂肪酸の同作用は

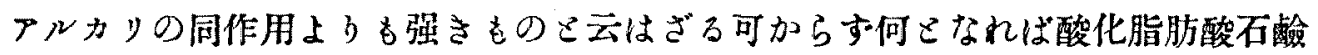
にてはトルオール法が滴定法より大なる結果を示せるが故なり

第三章 絹精練用石醶の学質度を測定する方法に就て

絹精練用の石䶨が變質せらや否やを知る事從て精練力を減殺せられ居るや否や を知る事は實際絹精練工場に於て石鹼の購入に當り之を簡單に試驗し得ば蝢る便 利なるのみならず石醶製造所に於ては原料を其製品の變質ての關係を見る上に於 て大切なる事項なりを踓を從來如斯き方法の發表せられたるを見ず然るに余が行 ひたる今包の研究により石襝の變質は要するに不能和脂肪酸石鹼の酸化にあるこ

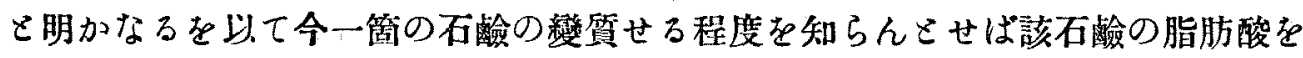
探收し之を石油エーラルにて處理し以て不溶性脂肪酸的ち酸化脂肪酸の量を測定 せば足れり己踓も少一層簡單にして且精練力をる同時に推測し得る方法の存在す

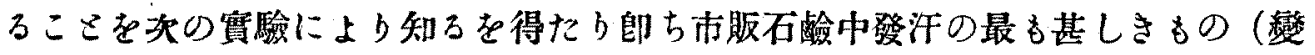


質の程度最も大なるもの）師ち第 1 表中の石畧 $\mathrm{F}, \mathrm{H}$ 及 $\mathrm{I}$ 並に發汗の少き $\mathrm{L} に$ 付 き先つ脂肪酸を分離し其の內不飽和脂肪酸の含量を检定し夫れに對する酸化脂肪 酸の量を算出し以て其割合(酸化率と假命す)を比敖せ 万該結果を加水分解度を併 せて表示すれば炏の如し

第 5 表

\begin{tabular}{|c|c|c|c|c|c|}
\hline \multirow{2}{*}{ 不龄名 } & \multirow[b]{2}{*}{ 瑟算度 } & \multirow[b]{2}{*}{ 脂棜酸の酸化率 } & \multicolumn{2}{|c|}{ 加水分解度 } & \multirow[b]{2}{*}{ 兩者の差 } \\
\hline & & & 滴定法 & $\overline{N \pi-U}$ 法 & \\
\hline$F$ & 甚大 & 14.6 & 23,25 & 25.00 & +1.75 \\
\hline HI & 甚大 & 25.0 & 17.50 & 24.75 & +7.25 \\
\hline I & 葸大 & $\mathbf{3 8 . 9}$ & 16.25 & 28.75 & +12.50 \\
\hline L & 少 & 6.6 & 37.00 & 24.50 & -12.50 \\
\hline
\end{tabular}

トルォール法に上る加水分解度が一般的に滴定法に於けるものよb小なるここ

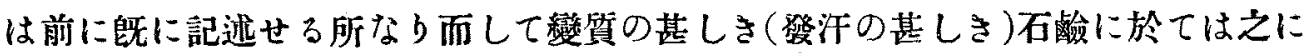
反しトルォール法による結果が涌定法の夫れよりる大なるここ亦已に記載せる所 なり而して上表により明かなる如くトルオール法に上る結果が滴定法のよりも大 なる場合は其酸化率も亦大なるものなるされば逆に石醶を構成する脂肪酸の酸化

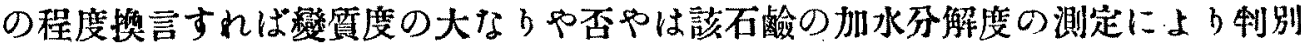
し得へさなり郎ち一つの石鹼の加水分解度を滴定法こトルオール法をにより測定 を篇し後者による結果が前者よりも大なる程酸化の度換言すれば變質つ度大なる ものなb

\section{概 括}

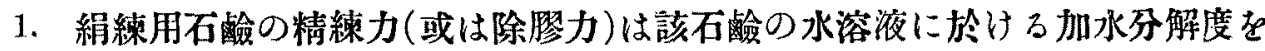
測定して之を知ることを得

2. 石䠯の加水分解度の測定方法さして數種を數ふれごも其の中最も實用的な るものは滴定法なり

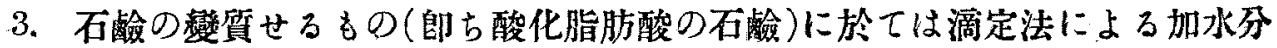
解度の大小は能く精練力の大小を表はせぎもトルオール法による加水分解度は全

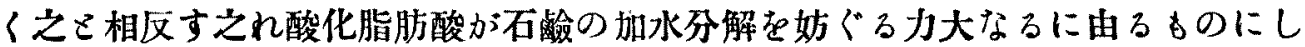
て從て筑質せる石䩎の精練力の檢定にはトルオール法を探用するここ能はず

4. 絹練石醶の變質せる程度を知らんこせば（換言すれば精練力減退の程度を

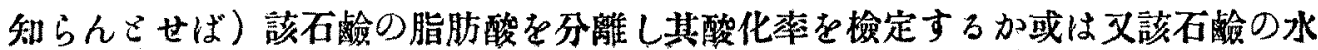


溶液に於ける加水分解度走滴定法並トルォール法にて测定し雨者の差を以て制别 し得へし

附 記 本研究の透行に當りては緗業試驗所技手尾川岸太君の手を煩はしたるもの 多々あり特記して感謝の意を表す

\section{引用書目次}

1. 絹業試驗所報告第 2 怣, P. 19 .

2. Lewkowitsch : Chem. Tech, \& Analysis of Oils, Fats \& Waxes, Vol. 1, P. 128.

3. 松本源坁. 工業化學會䌖誌，第26編，籍 3 删

4. Krafft u. Wiglow : Berichte, 1895, P. 2566.

5. 䅌業試驗所報告，第 1 卷，P. 14, P. 20.

6. Mc Bain u. Taylor: Berichte, 1910; P. 321. 